\title{
Arti Penting Asas Keterbukaan Dalam Penyelenggaraan Pemerintahan Yang Bebas Dari Korupsi, Kolusi, Dan Nepotisme (KKN)
}

\author{
Ridwan
}

\begin{abstract}
In a democratic state, transparent operation of state power and governance is reguired in order for law to function effectively and for democracy to senve as the mechanism of governance and state power. Transparancy is a key strategic instrument in the implementation of democratic and sound governance. Because of the strategic importance of transparency, it should become a principle within state governance. For this reason, the actions of the government should be able to be evaluated in the administrative court.
\end{abstract}

\section{Pendahuluan}

Ada harapan baik bagi bangsa Indonesia terhadap pemerintahan baru. Presiden Susilo Bambang Yudoyono (SBY) dalam beberapa kesempatan mengungkapkan akan memimpin sendiri secara langsung pemberantasan KKN yang seakan-akan sudah berurat berakar di negeri ini. Di hadapan Gubernur seluruh indonesia secara tegas Presiden mengatakan akan memberhentikan Gubernur yang terlibat KKN, sambil mengeluarkan sembilan instruksi, yang salah satunya berpesan kepada Gubernur agar memberi contoh sebagai pejabat yang bersih dari KKN. Pejabat yang terlibat KKN harus diberhentikan.' Tekad untuk memberantas KKN dijadikan sebagai program utama 100 hari pertama pemerintahan SBY. Dasar pijakan pemberantasan KKN adalah undang-undang yang telah dibuat sejak masa pemerintahan Habibie, yakni UU No. 28 Tahun 1999 tentang Penyelenggaraan Negara yang Bersih dan Bebas dari Korupsi, Kolusi, dan Nepotisme (KKN), di samping tentu saja undang-undang pidana korupsi. Bangsa Indonesia tentu saja berharap pemerintahan SBY bukan saja mampu mengimplementasikan UU No. 28 Tahun 1999, tetapi yang lebih penting lagi pemerintahan SBY mampu melenyapkan penyakit kronis bangsa ini; KKN.

Selama ini Undang-Undang pemberantasan KKN terkesan sebagai undang-undang yang

\footnotetext{
${ }^{1}$ Harian Kompas, 26 Oktober 2004, hlm. 1
} 
masih tertidur (slaapende regeling), belum menjadi undang-undang yang terbangkitkan (ontwaken regeling) yang secara efektif melenyapkan atau setidak-tidaknya mengurangi perilaku KKN. Banyak pengamat mengungkapkan bahwa perilaku KKN dari para penyelenggara negara dan pemerintahan baik di tingkat pusat maupun di tingkat daerah bukannya berkurang tetapi malah merebak dan terbukti masih sebagai negara paling korup di Asia. Kehadiran UU pemberantasan KKN sebenarnya patut dianggap sebagai langkah maju, meskipun belum berhasil terimplementasikan dengan baik. Memang, kegagalan pada level implementasi suatu peraturan adalah satu hal, sementara idealitas peraturan perundang-undangan dalam negara hukum adalah hal lain. Ketidakberhasilan atau belum terimplementasinya suatu peraturan ideal tidak sama maknanya dengan kegagalan para perumus peraturan. Keberhasilan implementasi peraturan masih memerlukan dan dipengaruhi oleh berbagai faktor. Karena itu, adalah tidak bijaksana ketika seseorang menganggap atau menimpakan kekeliruan pada perumus undang-undang, misalnya dengan mengatakan bahwa perumus undang-undang itu tidak realistik, terlalu utopis, dan bagai teriakan nyaring di belantara raya. Apapun adanya, lahirnya undang-undang tersebut harus dianggap sebagai langkah maju dan mempunyai arti penting yang dapat dijadikan instrumen dalam penyelenggaraan negara dan pemerintahan yang baik dan bersih dari perilaku menyimpang.

Kehadiran undang-undang tersebut menjadi lebih penting segera setelah UU No. 9 Tahun 2004 tentang Perubahan UU No. 5 Tahun 1986 tentang Peradilan Tata Usaha Negara (PTUN) menempatkan asas-asas yang terdapat dalam UU No. 28 Tahun 1999 sebagai salah satu alasan mengajukan gugatan ke PTUN. Di dalam UU No. 28 Tahun 1999 terdapat asas-asas yang sangat ideal untuk dijadikan rujukan dalam penyelenggaraan negara dan pemerintahan. ${ }^{2}$ Tulisan sederhana ini tidak akan membahas lebih jauh tentang faktor-faktor penyebab ketidakberhasilan implementasi UU No. 28 Tahun' 1999. Tulisan ini hanya akan mengkaji secara teoretik salah

${ }^{2}$ Asas-asas tersebut adalah Asas Kepastian Hukum; Asas Tertib Penyelenggaraan Negara; Asas Kepentingan Umum; Asas Keterbukaan; Asas Proporsionalitas; Asas Profesionalitas; Asas Akuntabilitas. Asas kepastian hukum adalah asas dalam negara hukum yang mengutamakan landasan peraturan perundangundangan, kepatutan, dan keadilan dalam setiap kebijakan penyelenggara negara; Asas tertib penyelenggaraan negara adalah asas yang menjadi landasan keteraturan, keserasian, dan keseimbangan dalam pengendalian penyelenggara negara; Asas kepentingan umum adalah asas yang mendahulukan kesejahteraan umum dengan cara yang aspiratii, akomodatif, dan selektif; Asas keterbukaan adalah asas yang membuka diri terhadàp hak masyarakat untuk memperoleh informasi yang benar, jujur, dan tidak diskriminatif tentang penyelenggaraan negara dengan tetap memperhatikan perlindungan atas hak asasi pribadi, golongan, dan rahasia negara; Asas proporsionalitas adalah asas yang mengutamakan keseimbangan antara hak dan kewajiban penyelenggara negara; Asas profesionalitas adalah asas yang mengutamakan keahlian yang berlandaskan kode etik dan ketentuan peraturan perundang-undangan yang berlaku; Asas akuntabilitas adalah asas yang menentukan bahwa setiap kegiatan dan hasil akhir dari kegiatan penyelenggara negara harus dapat dipertanggungjawabkan kepada masyarakat atau rakyat sebagai pemegang kedaulatan tertinggi negara sesuai dengan ketentuan peraturan perundang-undangan yang berlaku. 
satu asas yang terdapat dalam undangundang tersebut yaitu asas keterbukaan.

Keterbukaan (openbaarheid) dan keterbukaan pemerintahan (openbaarheid van bestuur) dalam suatu negara yang menempatkan rakyat sebagai pemegang kedaulatan dianggap sebagai instrumen penting untuk terselenggaranya kekuasaan negara dan pemerintahan yang baik dan demokratis. Prinsip bahwa rakyat sebagai pemegang kedaulatan menghendaki agar setiap penyelenggaraan kekuasaan negara dapat diketahui oleh rakyat, termasuk dalam hal mengungkap perilaku pejabat negara yang menyimpang. Begitu pentingnya keterbukaan ini sehingga tidak berlebihan jika dijadikan asas dalam penyelenggaraan kekuasaan negara dan pemerintahan dalam negara hukum demokratis.

\section{Negara Hukum Demokratis}

Menurut Budiono, sejarah pemikiran manusia mengenai politik dan hukum secara bertahap menuju ke arah kesimpulan bahwa, negara merupakan negara yang akan mewujudkan harapan para warga negara akan kehidupan yang tertib, adil, dan sejahtera jika negara itu diselenggarakan berdasarkan hukum sebagai aturan main. ${ }^{3}$ Upaya menempatkan hukum sebagai aturan main (spelregel) dalam penyelenggaraan negara dan pemerintahan telah melahirkan konsep negara hukum, sedangkan upaya menempatkan rakyat selaku pemegang kedaulatan dalam suatu negara telah melahirkan mekanisme demokrasi dalam penyelenggaraan negara dan pemerintahan. Negara yang diselenggarakan atas dasar negara hukum dan dijalankan melalui mekanisme demokrasi disebut negara hukum demokratis (democratiche rechtsstaat). Terdapat korelasi yang jelas antara negara hukum, yang bertumpu pada ketentuan hukum yang berlaku, dengan kedaulatan rakyat, yang dijalankan melalui sistem demokrasi. Negara hukum harus ditopang dengan sistem demokrasi. Hubungan di antara keduanya tidak dapat dipisahkan. Demokrasi tanpa pengaturan hukum akan kehilangan bentuk dan arah, sedangkan hukum tanpa demokrasi akan kehilangan makna. Menurut Magnis Suseno, "Demokrasi yang bukan negara hukum bukan demokrasi dalam arti yang sesungguhnya. Demokrasi merupakan cara paling aman untuk mempertahankan kontrol atas negara hukum". Secara sederhana, suatu negara disebut negara hukum demokratis ketika di dalamnya mengakomodir prinsip-prinsip negara hukum dan prinsip-prinsip demokrasi. ${ }^{5}$

Gagasan negara hukum demokratis

${ }^{3}$ Budiono Kusumohamidjojo, Ketertiban Yang Adil, Problematika Filsafat Hukum, (Grasindo, Jakarta, 1999), hlm. 147

${ }^{4}$ Frans.Magnis Suseno, Mencari Sosok Demokrasi, Sebuah Telaah Filosofis, (Gramedia, Jakarta, 1997), him. 58

5 Prinsip-prinsip negara hukum demokrasi: a. prinsip-prinsip negara hukum: 1) Asas legalitas; 2) Perlindungan hak-hak asasi; 3) Pemerintah terikat pada hukum; 4) Monopoli paksaan pemerintah untuk menjamin penegakan hukum; 5) Pengawasan oleh hakim yang merdeka. b. Prinsip-prinsip demokrasi: 1) Perwakilan politik; 2) Pertanggungjawaban politik; 3) Pemencaran kewenangan; 4) Pengawasan terhadap pemerintahan; 5) Kejujuran dan keterbukaan pemerintahan; 6) Rakyat diberi kemungkinan untuk mengajukan keberätan. Prinsip-prinsip ini disarikan dari, J.B.J.M. ten Berge, Besturen Door De Overheid, W.E.J. Tjeenk Willink, Deventer, 
muncul setelah sebelumnya kepada penyelenggara negara dan pemerintahan dibebani kewajiban untuk melayani dan mensejahterakan warga negara. Negara yang menempatkan pemerintah selaku pihak yang bertanggungjawab atas kesejahteraan warganya ini disebut negara hukum modem atau welfare state. Salah satu karakteristik paham negara kesejahteraan (welfare state) adalah adanya kewajiban pemerintah untuk mengupayakan bestuurszorg atau penyelenggaraan kesejahteraan sosial. Menunt E. Utrecht, adanya bestuurszorg ini menjadi suatu tanda yang menyatakan adanya suatu "welfare state". ${ }^{6}$ Bagir Manan menyebutkan bahwa dimensi sosial ekonomi dari negara berdasar atas hukum adalah berupa kewajiban negara atas pemerintah untuk mewujudkan dan menjamin kesejahteraan sosial (kesejahteraan umum) dalam suasana sebesar-besarnya kemakmuran menurut asas keadilan sosial bagi seluruh rakyat. Dimensi ini secara spesifik melahirkan paham negara kesejahteraan (verzorgingsstaat, welfare state). ${ }^{7}$ Suatu konsep negara yang secara historis di Eropa muncul sebagai bentuk peralihan dari negara hukum klasik (nachtwachtersstaat) yang menempatkan pemerintah hanya selaku penjaga ketertiban dan keamanan (rust en orde). ${ }^{\mathrm{B}}$

Indonesia dikatagorikan sebagai negara yang menganut konsep welfare state. Hanya saja, berbeda dengan konsepsi negara hukum kontinental, yang menganut paham welfare state setelah mengalami proses panjang dan peralihan dari negara hukum liberal, sejak awal terbentuknya Indonesia telah menganut paham negara kesejahteran. Hal ini dapat disimak dari pemikiran yang muncul pada saat perumusan UUD 1945. Yamin mengatakan; "...bahwa negara yang akan dibentuk itu hanya semata-mata untuk seluruh 'rakyat, untuk kepentingan seluruh bangsa yang akan berdiri kuat di dalam negara yang menjadi kepunyaannya". Lebih lanjut disebutkan; "Kesejahteraan rakyat yang menjadi dasar dan tujuan negara Indonesia Merdeka ialah pada ringkasnya keadilan masyarakat atau keadilan sosial". ${ }^{9}$ Menurut

1996, hlm. 34-38, lihat juga rumusan yang hampir senada, H.D. van WijkWillem Konijnenbelt, Hoofdstukken van Administratief Recht, Uitgeverij Lemma BV. Utrecht, 1995, hlm. 41-49, bandingkan juga dengan F.A.M. Stroink en J.G. Steenbeek, Inleiding in Het Staats-en Administratief Recht, Samsom H.D. Tjeenk Willink, Alphen aan den Rijn, 1985, hlm. 32

${ }^{6}$ E. Utrecht, Pengantar Hukum Administrasi Negara Indonesia, (Pustaka llmu, Surabaya, 1988), hlm. 30

${ }^{7}$ Bagir Manan, Pemikiran Negara Berkonstitusi di Indonesia, Makalah pada Temu IImiah Nasional "Memformat Indonesia Baru: Reformasi Hukum sebagai Fondasi Reformasi Totar, Fakultas Hukum Universitas Padjadjaran, Bandung, 6 April 1999, hlm. 2

${ }^{8}$ Konsep negara hukum klasik bertumpu pada dalil staatsonthoudingyakni pembatasan peranan negara dan pemerintah dalam bidang politik yang melahirkan dalil "The least government is the best governmenf, dan dalil "laissez faire, laissez aller" dalam bidang ekonomi yang melarang negara dan pemerintah mencampuri kehidupan ekonomi masyarakat. Di sini pemerintah menjadi sangat pasit sehingga disebut dengan negara penjaga malam (nachtwakerstaat). Sementara konsep negara hukum modern (welfare state) berpegang pada dali staatsbemoeienis yang menghendaki negara dan pemerintah terilibat aktif dalam kehidupan ekonomi dan sosial masyarakat, sebagai langkah untuk mewujudkan kesejahteraan umum (bestuurszorg).

${ }^{9}$ dikutip dari Azhary, Negara Hukum Indonesia, (UI-Press, Jakarta, 1995), hlm. 69 
Hamid S. Attamimi, bahwa Negara Indonesia memang sejak didirikan bertekad menetapkan dirinya sebagai negara yang berdasar atas hukum, sebagai Rechtsstaat. Bahkan Rechtsstaat Indonesia itu ialah Rechtsstaat yang "memajukan kesejahteraan umum", "mencerdaskan kehidupan bangsa", dan "mewujudkan suatu keadilan sosial bagi seluruh rakyat Indonesia". Rachtsstaat itu ialah Rachtsstaat yang material, yang sosial, yang oleh Bung Hatta disebut Negara Pengurus, suatu terjemahan Verzorgingsstaat. ${ }^{10}$ Konsep welfare state Indonesia juga dapat dilihat pada beberapa pasal di dalam Batang Tubuh UUD 1945." Dengan merujuk pada unsur-unsur negara hukum demokratis, negara Indonesia juga dapat dikatagorikan sebagai negara hukum demokratis, sekaligus juga menganut konsepsi negara kesejahteraan.

\section{Tugas dan Peranan Pemerintah dalam Negara Hukum Demokratis}

Cita-cita merealisasikan konsepsi negara hukum demokratis yang berorientasi kesejahteran rakyat telah menempatkan pemerintah selaku pihak yang bukan saja dibebani kewajiban untuk mengupayakan kesejahteraan bagi warga negara, tetapi juga pihak yang harus senantiasa memperhatikan aspirasi rakyat yang berkembang dinamis. $\mathrm{Di}$ samping itu pemerintah juga harus tetap berpedoman pada peraturan yang berlaku. Dalam hal ini tugas dan peranan pemerintah dihadapkan pada tiga batasan; peraturan hukum, aspirasi rakyat, dan kesejahteraan warga negara. Bagi pemerintah menjalankan tugas dan peranan dengan tiga batasan tersebut bukan perkara mudah. Ketiga batasan itu menyimpan permasalahannya masing-masing yang tidak mudah bagi pemerintah untuk memecahkannya.

Peraturan hukum menjadi dasar bagi pemerintah untuk melaksanakan tugas dan peranannya. Peraturan hukum terutama dalam bentuk undang-undang atau peraturan daerah, yang meskipun dibuat bersama-sama dengan wakil rakyat dan secara formal dianggap sebagai wujud konkret aspirasi rakyat (de wet als uiting van de volkswi), pada kenyataannya tidak selalu mencerminkan aspirasi riil dari rakyat yang diwakilinya. Sering terjadi kesenjangan antara aspirasi rakyat dengan apa yang disampaikan wakil rakyat ketika dirumuskan dalam undang-undang atau peraturan daerah. Di sini pemerintah sering dihadapkan pada pilihan dilematis; berpijak pada rumusan undang-undang formal yang dirumuskan wakil rakyat namun tidak selalu sejalan dengan aspirasi rill atau memperhatikan aspirasi riil dari rakyat meskipun tidak bertumpu pada undang-undang formal. Di sisi lain,

${ }^{10}$ Hamid S. Attamimi, Der Rechtsstaat Republik Indonesia dan Perspektifnya Menurut Pancasila dan UUD 1945, Makalah pada Seminar Sehari dalam Rangka Dies Natalis Universitas 17 Agustus Jakarta ke-42, Fakultas Hukum Universitas 17 Agustus, Jakarta, 9 Juli 1994, hlm. 17

"Ketentuan tersebut antara lain disebutkan di dalam UUD Negara Republik Indonesia Tahun 1945 Pasal 27 (Jaminan penghidupan yang layak), Pasal 28 (pengakuan dan perlindungan HAM), Pasal 29 (jaminan kebebasan beragama), Pasal 31 (penyelenggaraan sistem pendidikan), Pasal 32 (pemajuan budaya daerah dan nasional), Pasal 33 (pemanfaatan sumber daya alam untuk kemakmuran rakyat), dan Pasal 34 (pemeliharaan terhadap kaum fakir miskin). 
merigikuti aspirasi rakyat juga bukan persoalan mudah, karena aspirasi rakyat adalah konsep ambigu. Aspirasi rakyat mana yang harus diperhatikan? Upaya mewujudkan kesejahteraan bagi warga negara lagi-lagi juga bukan persoalan mudah. Mewujudkan kesejahteraan warga negara identik dengan biaya mahal, sementara sumber pembiayaannya sebagian berasal dari rakyat. Alih-alih mencapai kesejahteraan warga negara, yang terjadi malah membebani kehidupan ekonomi warga negara. Agaknya keterbukaan pemerintahan dapat menjadi solusi untuk menjembatani dilema dan problem-problem tersebut di atas. Karena dilema dan problem-problem itu senantiasa mengiringi tugas dan peranan pemerintah, maka keterbukaan pemerintahan ini harus menjadi bagian dan praktek dari sistem administrasi pemerintahan negara. Keterbukaan pemerintahan harus memainkan peranan penting dalam hubungan antara organ pemerintahan dengan warga negara. Keterbukaan tidak hanya penting untuk pergaulan (verkeer) antara warga negara dengan organ pemerintahan, tetapi juga penting untuk pelaksanaan pemerintahan yang baik dan demokratis. ${ }^{12}$ Dalam perkembangan lebih lanjut, keterbukaan pemerintahan ini akan mengarah pada penyelenggaraan pemerintahan secara horisontal (horizontal bestuur). Pemerintahan horisontal adalah strategi pemerintahan baru yang dicirikan oleh konsultasi dan negosiasi dengan warga negara sebelum pemerintah mengambil keputusan atau menetapkan kebijakan publik. ${ }^{13}$ Seiring dengan kedewasaan dan kecerdasan warga negara, model pemerintahan imperatif dan hubungan sepihak secara vertikal atasan-bawahan antara pemerintah dengan rakyat dianggap tidak lagi relevan..$^{14}$

\section{Keterbukaan Penyelenggaraan Negara dan Pemerintahan}

Dalam negara hukum demokratis, sebenarnya keterbukaan itu merupakan jaminan (waarborg) yang seharusnya ada atau sebagai conditio sine quanon, bukan sesuatu yang muncul secara kebetulan (toevallig). Pengawasan parlemen yang diselenggarakan dalam bentuk rapat umum dan pengawasan hakim yang terbuka untuk umum adalah contoh dari keterbukaan. ${ }^{15}$ Keterbukaan menjadi sangat penting artinya untuk terselenggaranya pemerintahan yang baik dan demokratis. Dapat dikatakan bahwa keterbukaan dianggap sebagai suatu prinsip hukum ketatanegaraan (staatrechtelijk beginsel) untuk terselenggaranya kekuasaan

${ }_{12}$ P. Nicolai, et.al., Bestuursrecht, Amsterdam, 1994, hlm. 183

${ }^{13}$ H.D. Stout, De Betekenissen van de Wet, Theoretisch-Kritische Beschouwingen over het Principe van Wetmatigheid van Bestuur, W.E.J. Tjeenk Willink, Zwolle, 1994, hlm. 208

${ }^{14}$ Pemerintahan horizontal muncul sebagai konsekuensi konsep negara pelayan (verzorgingsstaat), perkembangan teknologi, kemajuan pendidikan rakyat, dan sebagainya. Disebutkan bahwa latar belakang kemunculannya karena adanya pemencaran kekuasaan politik atau pluralisme kekuasaan (de versnippering van de politieke machf), kesalingtergantungan kedua belah pihak antara pemerintah dengan organisasiorganisasi kemasyarakatan (de wederzijdse afhankelijkheid van de overheid en maatschappelijke organisatie), dan perubahan struktur kepentingan (de veranderde structuur van de belangen), H.D. Stout, Ibid., hlm. 107 
yang baik. ${ }^{16}$ Penyelenggaraan kekuasaan negara tidak berada dalam ruang hampa, tetapi berhadapan dengan warga negara negara, yang secara konseptual diakui selaku pemilik kedaulatan dan kekuasaan. Selaku pemilik kedaulatan, warga negara berhak bukan saja mengetahui bagaimana kekuasaan negara itu dijalankan tetapi juga terlibat dalam penyelenggaraan kekuasaan tersebut secara langsung atau tidak langsung. Oleh karena itu dalam penyelenggaraan negara diperlukan keterbukaan (openbaarheid) dan kejujuran (openheid). Menurut P. De Haan dan kawankawan, keterbukaan adalah suatu keadaan dimana setiap warga negara dapat memperoleh informasi tentang: proses pembentukan keputusan di dalam pemerintahan yang terbuka; ini mengimplikasikan bahwa keterangan dan prosedur pembuatan keputusan itu diketahui umum atau dapat diakses masyarakat umum. Kejujuran menunjuk pada mentalitas (penyelenggara kekuasaan negara) yang disifati dengan kesiapan untuk memberikan informasi dan kesiapan untuk menanggapi pendapat yang berbeda. Di satu sisi, keterbukaan meletakkan kewajiban bagi pemerintah untuk memberikkan informasi, dan di sisi lain memberikan hak bagi warga negara untuk memperoleh informasi. Dalam Hukum Administrasi, keterbukaan untuk memperoleh informasi ini meliputi keterbukaan sidang atau pertemuan (openbaarheid van vergadering), keterbukaan prosedural (openbaarheid van procedures), dan keterbukaan mengakses dokumen (openbaarheid van register). ${ }^{17}$ Asas keterbukaan ini mempunyai fungsi-fungsi penting, yaitu; pertama, fungsi partisipasi; keterbukaan sebagai alat bagi warga untuk ikut serta dalam proses pemerintahan secara mandiri; kedua, fungsi pertanggungjawaban umum dan pengawasan keterbukaan; pada satu sisi sebagai alat bagi penguasa untuk memberi pertanggungjawaban di muka umum, pada sisi lain sebagai alat bagi warga untuk mengawasi penguasa; ketiga, fungsi kepastian hukum; keputusan-keputusan penguasa yang menyangkut kedudukan hukum para warga demi kepentingan kepastian hukum harus dapat diketahui, jadi harus terbuka; keempat, fungsi hak dasar; keterbukaan dapat mengajukan penggunaan hak-hak dasar seperti hak pilih, kebebasan berpendapat, dan hak untuk berkumpul dan berbicara. ${ }^{18}$

Keterbukaan dalam penyelenggaraan negara sangat menarik untuk dikaji lebih jauh karena di dalamnya menyangkut proses demokratisasi, proses politik dan penentuan kebijakan negara yang transparan, kejujuran para penyelenggara negara, perlindungan hak asasi manusia, kebebasan warga negara, dan sebagainya. Dapat dikatakan bahwa keterbukaan dalam penyelenggaran negara dan pemerintahan akan menghilangkan atau sekurang-kurangnya

15. dapat ditambahkan contoh dari keterbukaan ini yaitu seperti fit and proper test secara terbuka bagi calon-calon pejabat publik, pengumuman kekayaan pejabat-pejabat negara sebelum dan sesudah menjabat, debat terbuka para kandidat pemimpin bangsa, dan sebagainya.

${ }^{16}$ Lebih jauh lihat P. de Haan, et.al., Bestuursrecht in de Sociale Rechtsstaat, deel 2, Kluwer-Deventer, 1986, hlm. 121-122

${ }^{17} \mathrm{lbid.}$, hlm. 122-124

18. Philipus M. Hadjon, et.al., Pengantar Hukum Administrasi Indonesia, Gadjah Mada University Press, 1993, hlm. 282-283 
mengurangi perilaku KKN. ${ }^{19}$ Meskipun demikian, dalam tulisan ini hanya ditekankan pada keterbukaan pemerintahan atau administrasi negara dalam menjalankan tugas dan kewenangannya.

Dalam negara hukum demokratis, yakni negara yang diselenggarakan berdasarkan hukum dan hukum yang dibentuk itu sebanyak mungkin menampung aspirasi rakyat, kehadiran lembaga perwakilan rakyat dan lembaga peradilan - dua pilar utama negara hukum demokratis - agaknya masih memerlukan instrumen lain sebagai penopang untuk lahirnya pemerintahan yang ideal, dalam arti pemerintahan yang bukan saja sejalan dengan kebijakan yang dirumuskan oleh wakilwakil rakyat tetapi juga mematuhi ketentuan hukum yang berlaku. Instrumen penopang tersebut adalah keterbukaan pemerintahan (openbaarheid van bestuur) dan saluran pengaduan rakyat (inspraak) atas tindakan pemerintahan yang melanggar hak-hak rakyat. Dalam kepustakaan disebutkan bahwa untuk melaksanakan inspraak, keterbukaan dalam bentuk pertemuan atau rapat, keterbukaan informasi, prosedur, dan register, merupakan syarat primer. Keterbukaan dan inspraak disebut sebagai jaminan penyelenggaraan pemerintahan (yang baik dan demokratis), dan keduanya dianggap sebagai satu kesatuan. Inspraak adalah kelanjutan dari keterbukaan. ${ }^{20}$
Kehadiran dua instrumen penopang ini menjadi penting artinya terutama ketika lembaga perwakilan rakyat belum atau tidak berhasil menampung aspirasi rakyat secara maksimal dan ketika lembaga peradilan belum mampu mewujudkan rasa keadilan masyarakat. Tanpa bermaksud meragukan kredibilitas lembaga perwakilan rakyat sebagai pilar negara demokrasi yang berfungsi menyuarakan aspirasi rakyat, berbagai kendala teknis dan kelemahan sumber daya manusia, dapat menjadi penyebab tidak maksimalnya peranan lembaga tersebut dalam menampung dan menyuarakan aspirasi rakyat, bahkan patut pula diperhatikan kritik lama - di samping kritikkritik yang berkembang selama ini terhadap lembaga perwakilan rakyat - dari J.J. Rousseau yang pernah mengatakan; "Begitu ada badan perwakilan rakyat (parlemen) maka pada saat itu demokrasi menjadi tidak ada". ${ }^{21}$ Tanpa juga bermaksud meragukan kemampuan lembaga peradilan sebagai pilar negara hukum dalam menegakkan hukum dan mewujudkan keadilan, rutinitas teknis dan keterbatasan kemampuan daya nalar filosofi yuridis, di samping kendala-kendala lainnya, telah menyebabkan lembaga ini belum maksimal mewujudkan keadilan. Berbagai kritik telah banyak dilontarkan pada lembaga ini yang menunjukan kurang berperan secara maksimal bahkan yang bernada peyoratif seperti hakim

${ }^{19}$ Kolusi adalah kerja sama rahasia untuk maksud tidak terpuji atau persekongkolan; korupsi adalah penyelewenangan atau penggelapan (uang negara) untuk kepentingan pribadi atau orang lain; nepotisme adalah kecendenungan untuk mengutamakan (menguntungkan) sanak saudara sendiri, terutama dalam jabatan, pangkat di lingkungan pemerintah atau tindakan memilih kerabat atau sanak saudara sendiri untuk memegang pemerintahan. Ketiadaan keterbukaan sangat memungkinkan terjadinya perilaku KKN.

${ }^{20}$ P. de Haan, op. cit., him. 138

${ }^{21}$ Dikutip dari kata pengantar Afan Gaffar, Kualitas Pemilu Menenitukan Kualitas DPR, sebuah Sketsa, pada Buku, Pemilu dan Lembaga Perwakilan dalam Ketatanegaraan Indonesia, (Jurusan Hukum Tata Negara, Fakultas Hukum Ull, Yogyakarta, 1992), hlm. vii 
hanya corong undang-undang formal, putusan pesanan, jual beli putusan, dan lain-lain. Untuk mengatasi kelemahan bekerjanya pilar-pilar demokrasi dan cita-cita negara hukum, keterbukaan pemerintahan dianggap penting guna memaksimalkan berfungsinya demokrasi dan terwujudnya negara hukum serta perlindungan hak-hak asasi manusia.

Dalam perkembangan konsepsi negara hukum dan demokratisasi kehidupan bemegara, terutama di negara-negara berkembang, keterbukaan pemerintahan telah menjadi tuntutan internal dari warga negara untuk terealisasinya supremasi hukum, kehidupan demokratis, dan perlindungan hak-hak warga negara. Tuntutan ekstemal muncul dari Bank Dunia dan negaranegara donor, yang mensyaratkan masing-masing negara berkembang untuk menjalankan pemerintahan secara demokratis, transparan, menghormati hak-hak asasi manusia, dan dapat dipertanggungjawabkan kepada publik. Pada akhirnya, keterbukaan pemerintahan menjadi sesuatu yang tak terelakkan dalam perkembangan global saat ini, dan agaknya telah menjadi kemestian dalam pergaulan internasional.

Asas keterbukaan diangkat dari asas demokrasi dalam pelaksanaan pemerintahan yang menunjukan bahwa asas demokrasi tidak saja dilaksanakan melalui badan perwakilan rakyat, tetapi juga oleh setiap warga masyarakat sehubungan dengan tindak pemerintahan berupa keputusan..$^{22}$ Sebelum keputusan dikeluarkan, terutama keputusan yang bersifat memberi beban (belastende beschikking) atau yang berupa pemberian sanksi, pemerintah terlebih dahulu mendengar pendapat pihak yang akan dikenai keputusan. Secara teoretik dan historik, asas keterbukaan pemerintahan ini merupakan perkembangan dari asas permainan yang layak (principle of fair play) yang terdapat dalam asas-asas umum pemerintahan yang layak (algemene beginselen van behoorlijk bestuur), yakni asas yang menghendaki bahwa badan-badan pemerintahan harus memberikan kesempatan yang seluas-luasnya kepada warga negara untuk mencari kebenaran dan keadilan. Asas ini sangat penting karena adalah sangat mudah bahwa badan-badan pemerintahan memberikan keterangan-keterangan yang kurang jelas ataupun bahkan keteranganketerangan itu bersifat berat sebelah ataupun bersifat subyektif. ${ }^{23}$ Wiarda mengatakan bahwa asas fair play adalah sikap yang dituntut atau diharapkan dari pemerintah untuk melakukan keterbukaan, kejujuran, dan sikap tidak memihak (onpartijdig). Pemerintah harus memberikan kesempatan atau hak kepada warga negara untuk mengemukakan pandangan dan pembelaannya. ${ }^{24}$

Belanda dapat dijadikan contoh mengenai keterbukaan pemerintahan. Di Belanda keterbukaan pemerintahan ini telah diformalkan dalam suatu undang-undang, yakni Wet Openbaarheid van Bestuur 1991. Di dalam undang-undang ini ada kewajiban bagi pemerintah untuk memberikan informasi yang bersifat aktif dan pasif (passive-en actieve informatieplicht). Kewajiban informasi pasif adalah kewajiban bagi pemerintah untuk

${ }_{22}$ Philipus M. Hadjon dalam Paulus E. Lotulung, (ed.) Himpunan Makalah Asas-Asas Umum Pemerintahan yang Baik, (Citra Aditya Bakti, Bandung, 1994), hlm. 107

${ }^{23}$ Kuntjoro Purbopranoto, Beberapa Catatan Hukum Tata Pemerintahan dan Peradilan Administrasi Negara, (Alumni, Bandung, 1975), him. 52-53 
memberikan informasi ketika ada permohonan dari warga negara (informatie op verzoek), sedangkan kewajiban informasi aktif adalah kewajiban pemerintah untuk memberikan informasi kepada warga negara atas inisiatif sendiri (infomatie uit eigen' beweging). ${ }^{25}$

Keterbukaan pemerintahan bukan berarti memberikan informasi seluas-luasnya tanpa batas kepada warga negara, juga bukan berarti warga negara dengan bebas mengetahui semua informasi yang berkenaan dengan tugas, kewajiban, dan semua kegiatan pemerintahan. Ada batasan-batasan yang harus diperhatikan. Hal-hal yang menyangkut rahasia negara dan pemerintahan, keamanan negara, dan berbagai masalah yang menurut pertimbangan kemaslahatan tidak perlu -diketahui umum sudah barang tentu tidak termasuk sesuatu yang harus diinformasikan. ${ }^{26}$ Guna menopang keterbukaan pemerintahan ini diperlukan mekanisme lain yaitu forum pengaduan atau lembaga peran serta masyarakat (inspraak), di samping tentu saja lembaga peradilan (rechtspraak). Kehadiran lembaga Ombudsman dan PTUN adalah mekanisme penopang keterbukan pemerintahan tersebut.

\section{Asas Keterbukaan sebagai Alasan Menggugat}

Berdasarkan Pasal 53 ayat (2) UU No. 9 Tahun 2004 tentang Perubahan UU No. 5
Tahun 1986 tentang PTUN alasan mengajukan gugatan adalah sebagai berikut:

Alasan-alasan yang dapat digunakan dalam gugatan sebagaimana dimaksud pada ayat (1) adalah:

a. Keputusan Tata Usaha Negara yang digugat itu bertentangan dengan peraturan perundang-undangan yang berlaku;

b. Keputusan Tata Usaha Negara yang digugat itu bertentangan dengan asasasas umum pemerintahan yang baik.

Di antara asas-asas umum pemerintahan yang baik itu adalah keterbukaan, yaitu asas yang membuka diri terhadap hak masyarakat untuk memperoleh informasi yang benar, jujur, dan tidak diskriminatif tentang penyelenggaraan negara dengan tetap memperhatikan perlindungan atas hak asasi pribadi, golongan, dan rahasia negara. Telah diketahui bahwa gugatan yang diajukan ke 'PTUN itu hanyalah berkenaan dengan tindakan hukum pemerintah yang dituangkan dalam bentuk KTUN. Kapan dan dalam hal bagaimana KTUN itu dianggap bertentangan dengan asas keterbukaan? KTUN merupakan instrumen hukum tertulis yang dibuat sepihak oleh pemerintah dan ditujukan secara individual pada seseorang atau badan hukum perdata tertentu. Apakah setiap orang atau badan hukum perdata yang akan dituju itu harus diberikan informasi terlebih dahulu atau yang bersangkutan diberikan hak untuk mencari informasi dengan memperkenankan

${ }^{24}$ Dikutip dari A.M.A. Maassen, De Algemene Beginselen van Behoorlijk Bestuur, N.N. Samsom, Alphen aan den Rijn, tt., hlm. 26, lihat juga J. in 't Veld, Beginselen van Behoorlikk Bestuur, Tjeenk Willing, Zwolle, 1985, hlm. 37-38, lihat juga C.J.N. Versteden, Inleiding Algemeen Bestuursrecht, Samsom H.D. Tjeenk Willink, Alphen aan den Rijn, 1984, hilm. 137

${ }^{25}$ vide Artikel 3 en 8 Wet Openbaarheid van Bestuur (WOB) 1991

${ }^{26}$ Dalam WOB ada rincian hal-hal yang tidak boleh diinformasikan, lihat artikel 10 
melihat dokumen-dokumen pemerintahan? Jika informasi itu harus disampaikan kepada pihak yang akan dikenai keputusan, lalu bagaimana caranya? Apakah diumumkan melalui Berita Negara atau Berita Daerah, padahal KTUN bersifat individual, bukan ditujukan untuk umum? Berbagai pertanyaan ini menunjukan bahwa penerapan asas keterbukaan sebagai alasan mengajukan gugatan ke PTUN bukanlah perkara mudah, apalagi rumusan asas keterbukaan yang terdapat dalam undang-undang tersebut masih sangat abstrak. Ada yang berpendapat bahwa implementasi asas keterbukaan ini menunggu yurisprudensi Hakim Administrasi. Akan tetapi, menyerahkan kepada Hakim Administrasi untuk mempertimbangkan apakah KTUN itu bertentangan atau tidak dengan asas keterbukaan tidak serta merta menghilangkan kerumitan. Malah dapat memunculkan kerumitañ baru. Tanpa tolok ukur dan kriteria yang jelas tentang asas keterbukan akan memungkinkan lahirnya putusan Hakim Administrasi yang beragam. Ketika putusan hakim itu beragam untuk perkara yang sama, yurisprudensi mana yang dijadikan rujukan? Karena adanya kerumitankerumitan penerapan asas keterbukaan dalam penyelesaian sengketa tata usaha negara, maka sebelum asas keterbukaan ini digunakan sebagai alasan mengajukan gugatan, terlebih dahulu harus dibuat tolok ukur atau kriteria yang jelas kapan dan dalam hal bagimana KTUN itu bertentangan dengan asas keterbukaan. Tolok ukur dan kriteria apakah KTUN itu bertentangan atau tidak dengan asas keterbukaan akan diketahui jika ada undang-undang tentang keterbukaan pemerintahan, seperti halnya yang berlaku di Belanda.

\section{Simpulan}

Dalam negara hukum demokratis, yang menempatkan hukum sebagai aturan main kehidupan berbangsa dan bernegara, dan menjadikan demokrasi sebagai mekanisme penyelenggaraan negara dan pemerintahan, keterbukaan merupakan instrumen penting guna menopang terwujudnya supremasi hukum, kehidupan demokratis, dan perlindungan hak-hak warga negara, serta untuk terselenggaranya pemerintahan yang baik dan demokratis. Begitu pentingnya keterbukaan ini sehingga sangat relevan untuk dijadikan asas dalam penyelenggaraan negara dan pemerintahan. Hanya saja ketika asas keterbukaan ini akan dijadikan salah satu alasan mengajukan gugatan di PTUN,. diperlukan adanya tolok ukur dan kriteria yang jelas tentang asas keterbukaan ini. Wallahu a'lam bi al-shawab.

\section{Daftar Pustaka}

Attamimi, Hamid S., Der Rechtsstaat Republik Indonesia dan Perspektifnya Menurut Pancasila dan UUD 1945, Makalah pada Seminar Sehari dalam Rangka Dies Natalis Universitas 17 Agustus Jakarta ke-42, Jakarta: Fakultas Hukum Universitas 17 Agustus, 9 Juli 1994.

Azhary, Negara Hukum Indonesia, Jakarta: UIPress, 1995.

Berge, J.B.J.M. ten, Besturen Door De Overheid, W.E.J. Tjeenk Willink, Deventer, 1996.

Hadjon, Philipus M., et.al., Pengantar Hukum Administrasi Indonesia, Yogyakarta: Gadjah Mada University Press, 1993. 
J. in 't Veld, Beginselen van Behoorlijk Bestuur, Tjeenk Willing, Zwolle, 1985.

Kusumohamidjojo, Budiono, Ketertiban Yang Adil, Problematika Filsafat Hukum, Jakarta: Grasindo, 1999.

Lotulung, Paulus E., (ed.) Himpunan Makalah Asas-Ásas Umum Pemerintahan yang Baik, Bandung: Citra Aditya Bakti, 1994.

Maassen, A.M.A., De Algemene Beginselen van Behoorlijk Bestuur, N.N. Samsom, Alphen aan den Rijn, tt.

Manan, Bagir, Pemikiran Negara Berkonstitusi di Indonesia, Makalah pada Temu IImiah Nasional "Memformat Indonesia Baru: Reformasi Hukum sebagai Fondasi Reformasi Total', Bandung: Fakultas Hukum Universitas Padjadjaran, 6 April 1999.

P. de Haan, et.al., Bestuursrecht in de Sociale Rechtsstaat, deel 2, Kluwer-Deventer, 1986.

P. Nicolai, et.al., Bestuursrecht, Amsterdam, 1994.
Purbopranoto, Kuntjoro, Beberapa Catatan Hukum Tata Pemerintahan dan Peradilan Administrasi Negara, Bandung: Alumni, 1975.

Stout, H.D., De Betekenissen van de Wet, Theoretisch-Kritische Beschouwingen over het Principe van Wetmatigheid van Bestuur, W.E.J. Tjeenk Willink, Zwolle, 1994.

Stroink, F.A.M. en J.G. Steenbeek, Inleiding in Het Staats-en Administratief Recht, Samsom H.D. Tjeenk Wịllink, Alphen aan den Rijn,. 1985.

Suseno, Frans Magnis, Mencari Sosok Demokrasi, Sebuah Telaah Filosofis, Jakarta: Gramedia, 1997.

Versteden, C.J.N., Inleiding Algemeen Bestuursrecht, Samsom H.D. Tjeenk Willink, Alphen aan den Rijn, 1984.

Wijk, H.D. van /Willem Konijnenbelt, Hoofdstukken van Administratief Recht, Uitgeverij Lemma BV. Utrecht, 1995. 